\title{
Homojen Glioblastoma Örneklerinin Yüksek Çözünürlüklü Genetik Teknolojiler ile Analizi
}

\author{
Mehmet Baysan(0000-0001-7359-2965) \\ İstanbul Şehir Üniversitesi Mühendislik ve Doğa Bilimleri Fakültesi, Bilgisayar Mühendisliği, İstanbul, \\ mehmetbaysan@sehir.edu.tr
}

Geliş Tarihi: 09.03.2018

Kabul Tarihi: 09.05.2018

\section{Öz}

Tümör içi genomik heterojenlik kanserlerde sıkça karşılaşılan bir durumdur. Normal şartlarda her bir hücrede her bir genin iki kopyası vardır ve bazı istisnalar dışında organizmanın farklı hücreleri aynı DNA dizisini taşır. Kanser hücrelerinde ise gerek mutasyonlar sonucu gerekse de DNA silinmeleri ve eklenmeleri sonucu bu düzenli yapı karmaşık ve heterojen bir yapıya dönüşür. Bu genetik heterojenliğin sebebi ve tümör oluşumundaki rolü, genetik veri üretebilme teknolojilerindeki gelişmeler 1şı̆̆ında son zamanlarda çokça çalışılan önemli bir problemdir. Aynı tümörden elde edilmiş yüksek çözünürlüklü homojen numuneler, heterojenliği anlamak için yapılan çalışmalarda büyük önem arz etmektedir. Gerek kanser dokusuna erişimdeki zorluklar, gerekse de finansal limitler böyle yüksek çözünürlüklü veri setlerinin elde edilmesi önünde engel oluşturmaktadır. Glioblastoma multiforme teşhis sonrası ortalama yaşam süresi yaklaşık on beş ay olan, en sık görülen ve en agresif beyin tümörüdür. Bu çalışmada bir glioblastoma hastasından alınan detaylı homojen ve heterojen numuneler kullanılarak elde edilmiş yüksek çözünürlüklü bir veri seti incelenip, yapılan analizler sunulacaktır.

Anahtar kelimeler: Kanser, Bioinformatik, Glioblastoma, DNA Dizileme, DNA Kopya Sayıs1

\section{Analysis of Homogeneous Glioblastoma Samples with High-Resolution Genomic Technologies}

\begin{abstract}
Intra-tumor genomic heterogeneity is a common feature in human cancers. Normally, there are two copies of each gene in a cell and all cells of an organism carries the same DNA sequence despite some exceptions. With mutations and copy number changes in cancer, this well-defined structure is impaired and transformed into a chaotic structure. Cause of these transformations and their role in tumor development and maintenance is an important problem of oncology. Recent technological improvements allow generation of high-resolution genomic data which can be utilized to address this problem. Obtaining high-resolution homogeneous samples that are obtained from a single cancer is critical to study intra-tumor genomic heterogeneity. Both experimental and financial limitations create difficulties in obtaining detailed data sets that includes such samples. Gioblastoma multiforme is the most common and most aggressive brain tumor with a median survival of fifteen months post diagnosis. In this manuscript, analysis results of a data set that includes high-resolution homogeneous and heterogeneous samples from a glioblastoma patient will be presented.
\end{abstract}

Keywords: Cancer, Bioinformatics, Glioblastoma, DNA Sequencing, DNA Copy Number

\section{GíRiş}

Yaşamı devam ettirecek vücut fonksiyonları ancak dokuların ve dokuları oluşturan hücrelerin birbiri ile uyumlu çalışması ile elde edilebilir. Sağlıklı dokularda gözlemlenen morfolojik ve yapısal düzen bu uyumlu çalışmayı sağlayan temel unsurlardan bir tanesidir. Kanserle birlikte bu düzen kaybolur ve hücreler heterojen ve dağınık bir şekilde görüntülenirler. $\mathrm{Bu}$ düzen kaybı sadece dış görünümde kalmaz. Mutasyonlar sonucu normal şartlarda tüm hücrelerde aynı kalması gereken genetik harita heterojenleşirken özellikle DNA metilasyonu gibi hücre içi fonksiyonları direk etkileyen epigenetik profillerde de heterojenleşme gözlemlenmiştir [1]. Kanser dokusundaki bu heterojenleşme kanser tanısı ve tedavisi adına büyük zorlukları da beraberinde getirmektedir. Tanı için kullanılan biopsiler birçok

*Sorumlu Yazar: İstanbul Şehir Üniversitesi Mühendislik ve Doğa Bilimleri Fakültesi, Bilgisayar Mühendisliği, İstanbul, mehmetbaysan@sehir.edu.tr 
zaman heterojen bir tümörün çok küçük bir kısmını temsil etmektedir ve yanıltıcı olabilmektedir. İşin tedavi boyutunda ise heterojenlik kanser hücreleri için korunma kalkanı olabilmektedir. Uygulanan herhangi bir tedavi kanser hücrelerinin çok büyük bir çoğunluğunu öldürebilse bile heterojen yapıdan dolayı tedaviye dirençli hücreler bulunabilmekte ve bu dayanıklı hücreler kısa zamanda çoğalarak kanserin tekrar etmesi ile neticelenmektedir [2].

Tümör içi heterojenlik tespitleri ve bu konudaki ilk çalışmalar 19. yüzyılda başlamıştır [3]. 20. yüzyılda aynı tümör içindeki farklı klonlara ait farklı hücrelerin gerek metastaz potansiyeli, gerekse de tedaviye dayanıklılık açısından farklı özellikler gösterdiği deneylerle gösterilmiştir [4-7].

Yakın zamanda, tek hücre siralaması (single cell sequencing) gibi modern genomik teknolojiler kullanılarak göğüs kanseri [8], böbrek kanseri [9], akciğer kanseri [10] gibi temel kanser tiplerinde tümör içi heterojenlik calışmaları yapılmış, özellikle pediatrik tümörler için tümör içi heterojenlik seviyesi ve tümör agresifliği arasında pozitif korelasyon gösterilmiştir [11]. Tümör içi heterojenlik ile ilgili önemli çalışmalar ve bunların tedavi ile ilgili potansiyel etkileri için yakın zamanlı derleme makalelerine [12] başvurulabilir.

Glioblastoma multiforme (GBM) en sık teşhis edilen ve en agresif beyin kanseridir. Bu kanserde ameliyat sonrası tümörün tekrar nüks etmesi kaçınılmazdır ve ilk teşhis sonrası kalan yaşam süresi ortalama on beş aydır [13, 14]. GBM dengesiz dağıtılmış nekrotik odaklar, hiperhücresel bölgeleri ve yüksek miktarda damar oluşumu gibi fenotipik özellikler ile daha düşük seviyeli gliomalardan ayrılır ve hastalık ismindeki "multiforme" nin de işaret ettiği gibi yüksek seviyede morfolojik heterojenlik sergiler [15].

20. yüzyıldaki genetik çalışmalar bu morfolojik heterojenliğe paralel olarak, tümör içi hücrelerin genetik profillerinin de heterojen olduğunu ortaya koymuştur [16]. 21. yüzyıl ile beraber özellikle insan genomu projesi sonrası genomik veri üretme teknolojileri gelişmiş, bu teknolojilerin GBM tümörlerine uygulanması sonucu yüksek seviyeli tümör içi heterojenlik ortaya konmuştur [17-20].

$\mathrm{Bu}$ çalışmalar beyin kanserlerinde yüksek evrelerde daha fazla tümör içi heterojenlik olduğunu göstermiş [21, 22] ve GBM özelinde daha heterojen tümörlerin daha kötü bir seyir izlediğini ifade etmiştir [20].

Tümör içi heterojenlik çalışmaları farklı yaklaşımlarla yapılabilmektedir. Bunlardan ilki yeni nesil yüksek çözünürlüklü sıralama teknolojisinin tümörden alınan tek örnek üzerinde uygulanmasıdır. Bu teknolojiler örnekteki DNA veya RNA`nın küçük parçalara bölünüp (30-300 nükleotid) bu parçaların okunması ve referans genoma yerleştirilip örneğin referans genomla farklılıkların belirlenmesine dayanır.

Her bir DNA bölgesi çok defa okunduğu için örnekteki herhangi bir DNA bölgesi heterojense (mesela hücrelerin yarısı referans genomla aynı yarısı farklı ise) bu o bölgedeki okumalara da yansıyacaktır. Bu okuma farkları kullanılarak heterojen bölgeler ve mutlak kopya sayıları (normalde her genin iki kopyası olması gerekir ama kanser dokusunda değişiklikler olabilir) tahmin edilebilir [23-25]. Tek örnek kullanıldığı için nispeten ucuz ve kolay olan bu yöntem birçok çalışmada kullanılmıştır $[12,26]$. Fakat elde edilen sonuçların ne kadar doğru olduğu detaylı olarak çalışılamamıştır ve bu durum bizim bu makalede kısmen de olsa cevaplandırmaya çalışacağımız önemli bir eksikliktir.

Bir tümörden alınan farklı örnekleri karşılaştırmak heterojenlik konusunda fikir vermek adına kullanışlı alternatif bir yaklaşımdır. Fakat ilk metodda olduğu gibi örneklerin herbiri çok miktarda heterojen hücre içerdiği için elde edilen veri bu hücre profillerinin ortalaması olmaktadır. Dolayısı ile heterojenlik ve mutlak kopya sayıları adına kesin kanaat verememektedir. Alternatif olarak tek bir hücrenin profilini incelemek için tek hücre bazlı sıralama teknolojileri (single cell sequencing) kullanılabilir fakat günümüzde bu teknolojiler (özellikle amplifikasyon işleminden ötürü) güvenilir yüksek çözünürlüklü bilgi verememektedirler.

Biz bu çalışmamızda heterojenliği analiz etmek için bir GBM hastasından alınan örneklerden laboratuar ortamında çoğaltılabilen heterojen ve homojen hücre hatlarını kullandık. Homojen hücre hatları, heterojen hücre hatlarından tek hücreler alınarak ve bu tek hücreleri çoğaltarak analiz edebilecek miktara ulaştırılarak oluşturuldu. Böylece aynı heterojen tümör örneğinden elde edilmiş yüksek çözünürlüklü homojen örneklere ulaşıldı. Bu homojen örnekler bize mutlak kopya sayıları ve herhangi bir mutasyonun kopyaların ne kadarında gözlemlendiği hakkında detaylı ve yeni bilgiler sundu. Makalenin geri kalanında önce teorik bir altyapı geliştirip sonra gözlemleri teorik beklentiler ile karşılaştıracağız. 


\section{MALZEME VE YÖNTEM}

\subsection{Yeni Nesil Dizileme Verisi}

Örneklerden elde edilen DNA, Ambry Genetics firmasına gönderildi ve yeni nesil sıralama teknolojisi ile fastq dosyalarına dönüştürüldü. Elde edilen okuma segmentleri insan genomuna(hg19) yerleştirildi ve örnekler için 40x ile 100x arası ortalama okuma derinliği elde edildi. Mutasyonları belirlemek için yaygın olarak kullanılan algoritmaları birleştirerek iki bağımsız sistem(pipeline) geliştirdik ve analizlerimizde sadece iki sistemin de bulduğu mutasyonları kullandık. Birinci sistem okumaları yerleştirme için BWA/GATK (http://bio-bwa.sourceforge.net/,

https://software.broadinstitute.org/gatk/) algoritmalarını ve mutasyon keşfi için Mutect (http://archive.broadinstitute.org/cancer/cga/mutect)

algoritmasını kullandı. İkinci sistem okumaları yerleştirme için NovoAlign (http://www.novocraft.com/products/novoalign/)

algoritmasını ve mutasyon keşfi için Varscan2(http://varscan.sourceforge.net/) algoritmasını kullandı. Mutasyon oranları ilk metod kullanılarak elde edildi.

\subsection{Kopya Sayısı Verisi}

Kopya sayısı için Affymetrix Human SNP array 6.0 and CytoScan ${ }^{\circledR}$ HD array mikrodizi teknolojisi kullanıldı. Hazırlanan DNA (QIAamp® DNA kit (Qiagen, Germany) ) mikrodizi üreticisinin tavsiyelerine uygun şekilde hibridize edildi, Affymetrix GeneChip ${ }^{\circledR}$ Fluidics Station 450 cihazı kullanılarak renklendirildi ve GeneChip ${ }^{\circledR}$ Scanner $3000 \quad 7 \mathrm{G}$ cihazı ile okundu. Oluşturulan CEL dosyaları Partek Genomics Suite kullanılarak analiz edildi ve herbir mutasyon için kullanılacak kopya sayısı verileri oluşturuldu.

\section{BULGULAR}

\subsection{Homojen bir örnekte nasıl bir kopya numarası ve mutasyon oranı gözlemlenir?}

İnsan hücrelerinde birisi anneden birisi babadan gelmek üzere herbir kromozomun (istisnalar hariç) iki kopyası vardır. Kanser hücreleri DNA'sında ise kopya sayısı değişimi ve mutasyon olmak üzere iki temel transformasyon gözlemlenir. Normalde iki olan kopya sayısı kromozomun tamamının veya bir bölümünün silinmesi ile bir veya sıfıra düşebilir ya da duplikasyonlar neticesi üç veya daha fazlaya çıkabilir. Genomik teknolojiler ile DNA'nın farklı bölgelerine ait kopya sayısı belirlenebilmekte, bizler de bu temel tanımları kullanarak homojen bir örnekteki kopya sayısı profilini simüle edebilmekteyiz. Bu çalışmada da kullandığımız platformlardaki teknik hata paylarını temsil edecek rasgele kaymalar (uniformly distributed random noise) da ekleyerek bu simülasyonları yaptık. Kanserli bir dokuda beklenilen kopya numarası profili Şekil 1A'da da gözlemlenebileceği üzere, DNA'nın büyük kısmı sağlıklı durum olan iki kopya sayısını muhafaza eder. Ancak silinme veya artma sonucu bazı bölgelerde değişen kopya sayıları farklı katmanlar oluşturur.

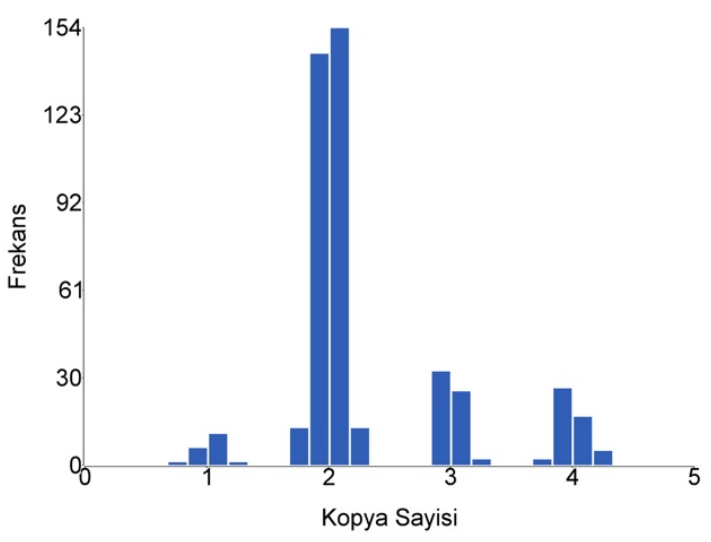

(A)

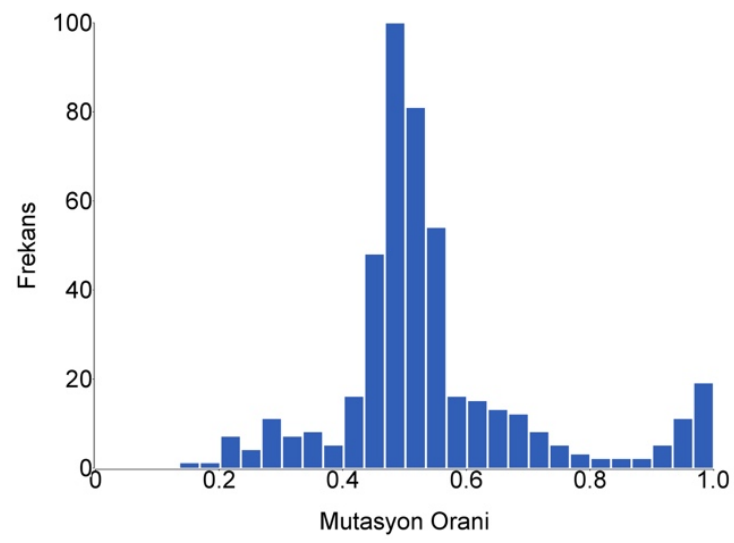

(B)

Şekil 1. Homojen bir tümör örneğine ait (A) simüle edilmiş kopya sayısı verisinin histogramı (B) simüle edilmiş mutasyon oranı verisinin histogramı.

Mutasyonlar sonucu tekli nükleotidler (A-G-C-T) değişkenlik gösterir; mesela normal hücrelerdeki A’nın tümörde C olması gibi. Mutasyon oranını örnekteki okunan kopyaların ne kadarının mutant olduğu olarak tanımlıyoruz. Mesela iki kopyalı bir DNA bölgesinde bir kopya mutant bir kopya normal ise mutasyon oranı 0.5 
dir. Eğer iki kopya da mutant ise mutasyon oranı 1.0 dir. Kanserli homojen bir dokuda beklenilen mutasyon oranı profili Şekil 1B'de gözlemlenebilir. Şekilde gözlemlendiği üzere mutasyonların çoğu DNA'nın iki kopyasının birinin değişmesi sonucu oluşur ve mutasyon oranı 0.5 bölgesinde kümelenir. Eğer mutasyon olan bölgede tek DNA kopyası varsa (diğeri silindiyse) mutasyon oranı 1.0 olur.

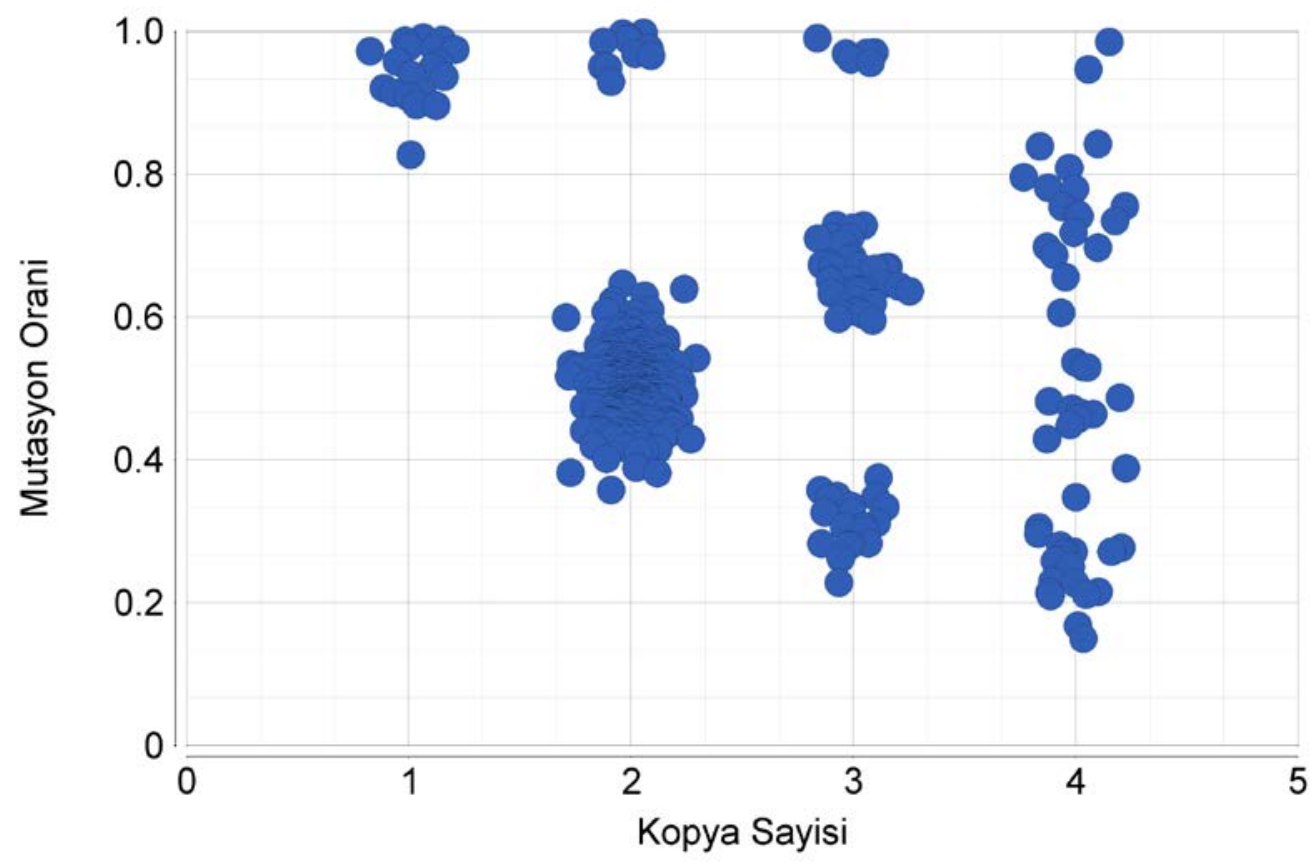

Şekil 2. Kopya sayısı ve mutasyon oranı ilişkisini gösteren dağılım grafiği (scatter plot). Her bir daire bir mutasyona işaret eder. X-aksisi kopya sayısını, y-aksisi mutasyona ait oranı gösterir.

Çalışmamızın bir sonraki aşamasında kopya sayısı ve mutasyon oranı profillerini birleştirdik. Şekil-2'de her bir mutasyon için $\mathrm{x}$ aksisine kopya sayısını, y aksisine mutasyon oranını yerleştirdik. Kopya sayıları homojen bir örnekte tam sayılar olmalıdır. Bu sebepten x aksisinde tam sayılarda katmanlar görüyoruz. Mutasyon oranları bu katmanlar içinde belli bölgelerde kümeleniyor. Mesela kopya sayısı üç olan bölgede sadece bir kopya mutantsa mutasyon oranı 0.33 , iki kopya mutantsa mutasyon oranı 0.66, üç kopya da mutantsa mutasyon oranı 1.0 civarında gözlemleniyor.

\subsection{Hastadan Elde Edilmiş Kanser Örneğinden Elde Edilen Sonuçlar}

Simüle edilmiş verilerle günümüz genetik kabüllerine göre oluşturulmuş beklentileri ifade ettikten sonra, bu kısımla birlikte gerçek kanser hücreleri üzerine yaptığımız analizlere geçiyoruz. Bundan bir kaç yıl önce, NIH
(National İnstitutes of Health, Bethesda, MD, USA) bünyesindeki bir proje kapsamında bir GBM hastası ölmeye yakın hastaneye yatırıldı ve ölür ölmez tümörün farklı bölgelerinden örnekler alındı [27]. Kanser içi heterojenliği çalışmak için her bir örnekten heterojen ve homojen hücre hatları oluşturuldu ve herbir örnekteki herbir mutasyon için kopya sayısı ve mutasyon oranı verilerini meydana getirildi. Hasta örneklerini incelediğimizde, elde edilen verinin simülasyonlardan oldukça farklı olduğunu görüldü (Şekil 3). Gerek kopya sayısında gerekse de mutasyon oranında birbiri ile ayrılmış net katmanlar görülememesi bize örneğin oldukça heterojen hücre gruplarından oluştuğunu ifade etti. Bunu destekleyen başka bir delil de 0.2-0.4 aralığında gözlemlenen farklı mutasyon oranları oldu. İlk aşamada bu mutasyonları örnek içindeki hücrelerin sadecebir kısmında bulunan heterojen mutasyonlar olarak nitelendirdik. 


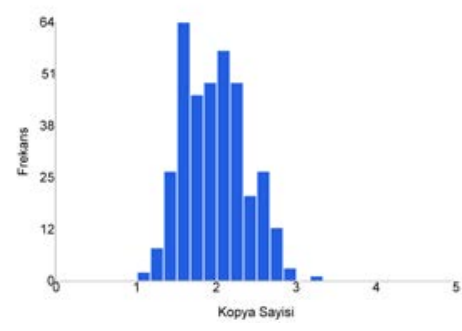

(A)

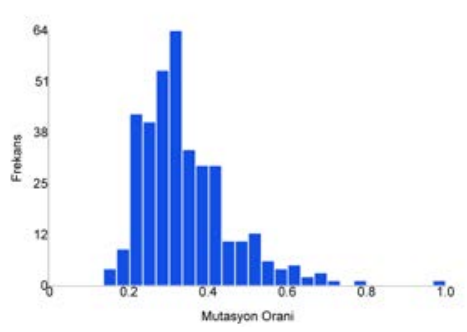

(B)

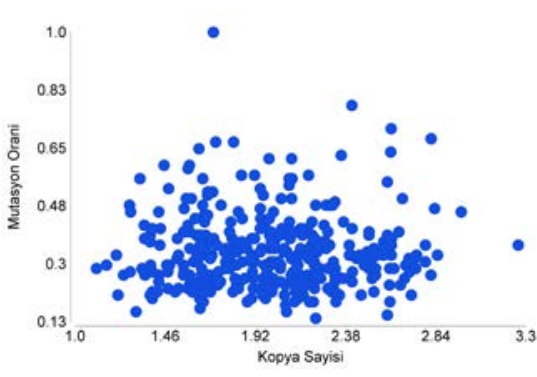

(C)

Şekil 3. Hastadan alınan T6 bölgesi için (A) kopya sayısı ve (B) mutasyon oranı verilerinin histogramları. (C) bu verilerin birleştirilmiş halinin dağılım grafiği (scatter plot). (C)'de Herbir işaret bir mutasyona işaret eder.

\subsection{Heterojen ve Homojen Hücre Hatları ile İlgili Sonuçlar}

$\mathrm{Bu}$ bölümde hücre hatları ile elde ettiğimiz sonuçları sunacağız. Yukarıda sunulan hasta örneğinden oluşturulan hücre hattını analiz ettiğimizde kopya sayısında 2, 2.5, 3 bölgelerinde bir toplanma (Şekil 4A, 4C) ve birçok homozigot mutasyon (Şekil 4B, 4C) gözlemlendi. Bu sonuçlar hücre hattının hasta tümörüne göre daha homojen olduğuna işaret etti. Öbür yandan özellikle Şekil 4C'de net ayrışmalar göremememiz heterojenliğin kısmen muhafaza edildiğini gösteriyordu.

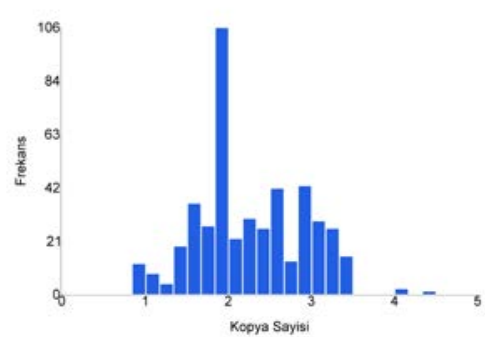

(A)

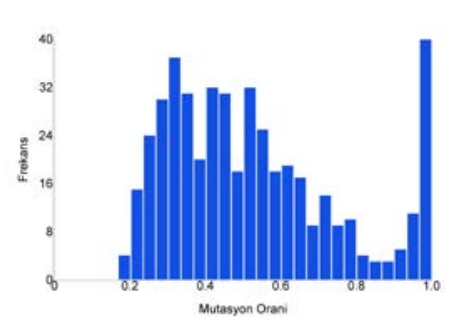

(B)

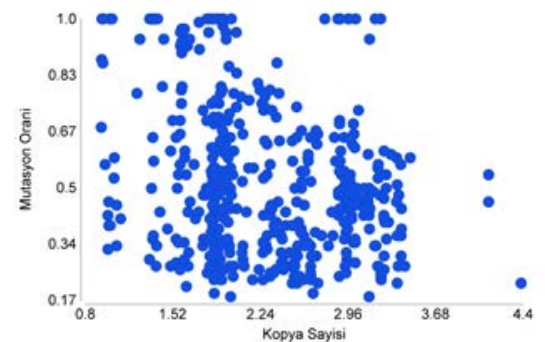

(C)

Şekil 4. T6'dan oluşturulan hücre hattı için (A) kopya sayısı ve (B) mutasyon oranı verilerinin histogramları. (C) bu verilerin birleştirilmiş halinin dağılım grafiği (scatter plot). (C)'de Herbir işaret bir mutasyona işaret eder.

Daha önce ifade edildiği gibi oluşturulan hücre hatlarından, tek bir hücre seçilip analiz için gerekli miktara ulaşıncaya kadar çoğaltılıp homojen hücre hatları elde edildi. Bu homojen hücre hatları analiz edildiğinde çok ilginç sonuçlar elde edildi (Şekil 5). Öncelikle kopya sayısında $1.3,2$ ve 2.8 civarında üç temel band gözlemlendi. Öncelikle genel kabul çerçevesinde; bu üç bandın 1,2 veya 3 kopya sayılarına işaret ettiğini düşündük. Fakat mutasyon oranları ile birleştirdiğimizde (Şekil 5C) bu bandların net bir şekilde 2,3 ve 4 kopyaya işaret ettiğini görüldü (1.3 kopya sayısı bandında mutasyon oranları 0.5 ve 1 alanında kümelenmiş, 2 kopya sayıs1 bandında mutasyon oranları $0.33,0.66$ ve 1 alanında kümelenmiş, 2.8 kopya sayısı bandında mutasyon oranları $0.25,0.5$ ve 1 alanında kümelenmiş). Kullandığımız çiplerde kanser hücreleri ve normal hücrelerden eşit miktarda DNA karşılaştırılarak sonuçlar elde edilmektedir. Ortalama kopya sayısının iki olacağı genel olarak kabul edildiği için bizde simülasyonlarda böyle sonuçlar elde etmiştik. Fakat analiz edilen homojen örnekte ortalama kopya sayısı üç olduğu için bu iki bantta gözlemlendi (mesela analiz ettiğimiz örnekte ortalama kopya 5 olsaydı, gerçekte 5 kopya sayısı olan bölgeler veri üreten algoritmadaki normalizasyon sonucu ortalama 2'ye denk gelecek şekilde kaydırılacak ve 2 bandında gözlemlenecekti). Kopya sayılarının ortalamasının 3 olması, literatüre alternatif ilginç bir sonuçtu buna ek olarak kopya sayılarının 2, 3, ve 4 kopya sayıları arasında birbirine yakın şekilde dağılması kanser hücresinde farklı DNA bölgelerinin kopya sayıları açısından yüksek heterojenlik gösterdiğini ifade etti.

Bunlara ek olan farklı bir gözlemse 3 ve 4 kopya sayısı olan bölgelerde mutasyon oranlarının dengeli bir şekilde dağılmadığı oldu. Kopya sayısı 3 olan bölgelerde 0.33 mutasyon oranı 0.66 mutasyon oranına göre daha fazla gözlemlendi. Benzer şekilde kopya sayısı 4 olan bölgelerde 0.25 ve 0.5 mutasyon oranı 0.75 mutasyon oranına göre daha fazla gözlemlendi. Bu gözlemler 
mutasyon taşımayan kopyaların mutasyon taşıyan kopyalara göre daha fazla olduğunu ve muhtemelen mutasyonların negatif bir seçime tabi tutulduğunu gösteriyordu.

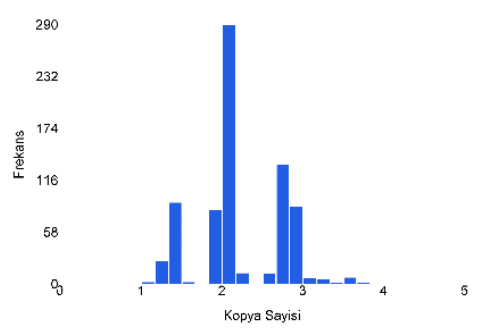

(A)

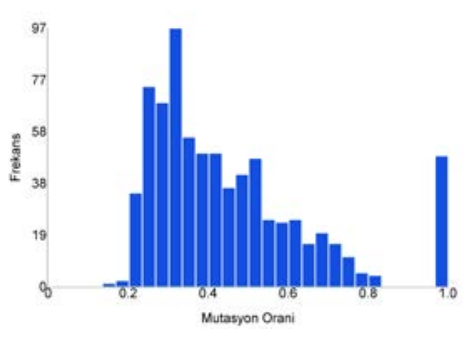

(B)

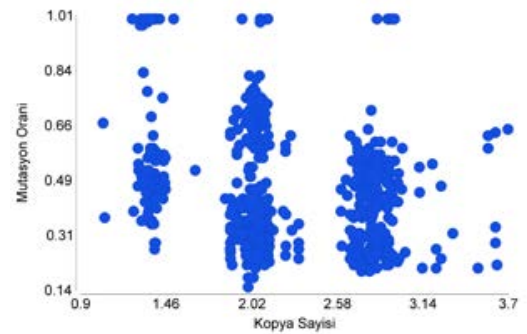

(C)

Şekil 5. T6'dan oluşturulan homojen bir hücre hattı için (A) kopya sayısı ve (B) mutasyon oranı verilerinin histogramları. (C) bu verilerin birleştirilmiş halinin dağılım grafiği (scatter plot). (C)'de Herbir işaret bir mutasyona işaret

eder.

\subsection{K-means Gruplama}

Homojen hücre hattında görsel olarak teorik profile benzer bir profil elde ettikten sonra, homojen ve heterojen örneklerde k-means gruplaması yaptık. Bu gruplamada amacımız, teorik olarak bildiğimiz grupların veri üzerinden pratikte tespit edilip edilemeyeceği idi. Kmeans gruplamasında iki farklı veri tipi kullandığımız için şehir bloğu (city block) mesafe ölçümünü tercih ettik. İdeal grup sayısını bulmak için 5-15 aralığındaki tüm sayılarla k-means algoritmasını çalıştırdık ve en az Davies Bouldin skorunu veren grup sayısını tercih ettik. $\mathrm{Bu}$ sayı homojen hücre kültürü için 8 (T6MC23, Şekil 6A), heterojen hücre kültürü için 13 (T6poly, Şekil 6B) ve hastadan alınan örnek için 9 (T6T, Şekil 6C) olarak elde edildi.

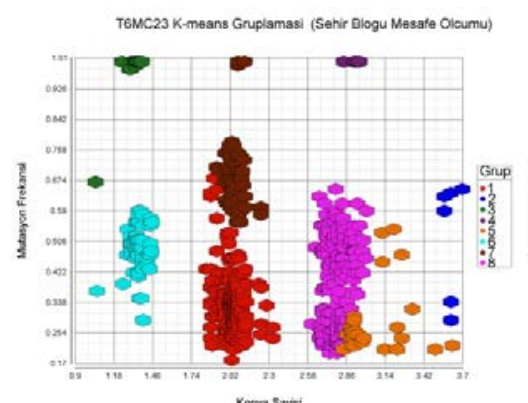

(A)

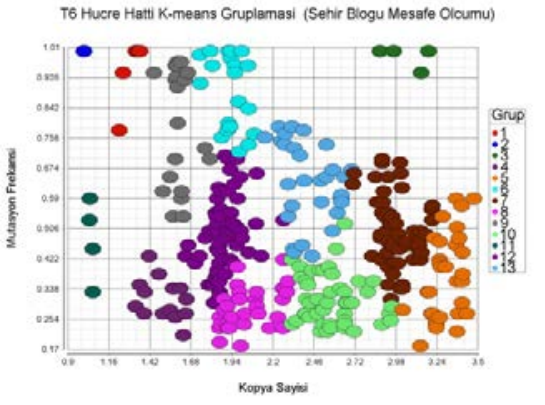

(B)

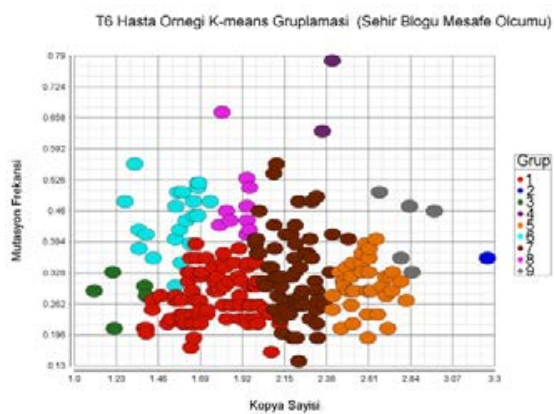

(C)

Şekil 6. T6 homojen hücre hattı (A), T6 heterojen hücre hattı (B) ve T6 hasta örneği (C) verileri için k-means gruplaması uygulanmış kopya sayısı ve mutasyon frekansı (oranı) profilleri. Herbir işaret bir mutasyona işaret eder ve mutasyonlar gruplamalara göre renklendirilmiştir.

Homojen bir hücre hattı için yukarıdaki gözlemleri yaptıktan sonra, farklı homojen hücre hatlarında bu gözlemlerin geçerli olup olmadığını sorguladık. Şekil 7'de iki homojen hücre hattını karşılaştırdık ve kopya sayısı ve mutasyon oranı profillerinin benzer olduğunu gözlemledik (Şekil 7A,7B). Şekil 7C'de aynı iki örnekte ortak görülen mutasyonları çizgiler ile birleştirdik. Bu çizgiler birçok mutasyonun farklı örneklerde farklı bandlarda olduğunu gösterdi. Mutasyonlar sadece silinme ve çoğalma gibi kopya sayısı değişimleri sonucu bant değiştirebilir. Dolayısı ile örnekler arası bu değişimler bu kanser hücrelerinin oldukça dinamik bir DNA kopya sayısı yapısı olduğunu gösterdi. 

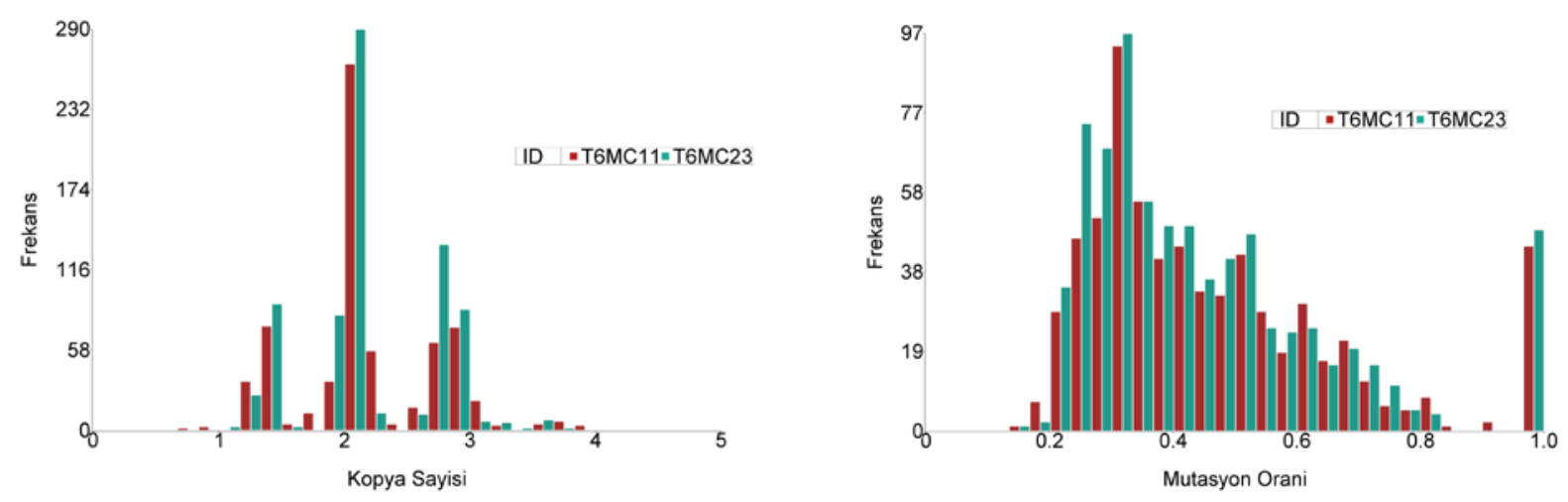

(A)

(B)

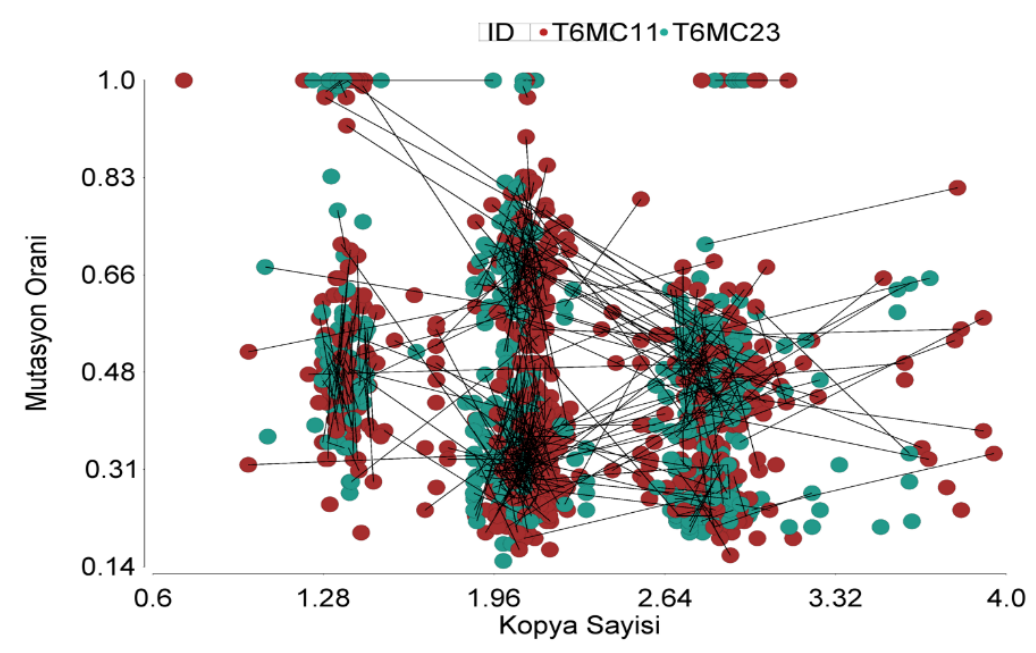

(C)

Şekil 7. T6'dan oluşturulan iki homojen hücre hattı için (A) kopya sayısı ve (B) mutasyon oranı verilerinin histogramları. (C) bu verilerin birleştirilmiş halinin dağılım grafiği (scatter plot). (C)'de Herbir işaret bir mutasyona işaret eder ve aynı mutasyonlar çizgi ile birleştirilmiştir.

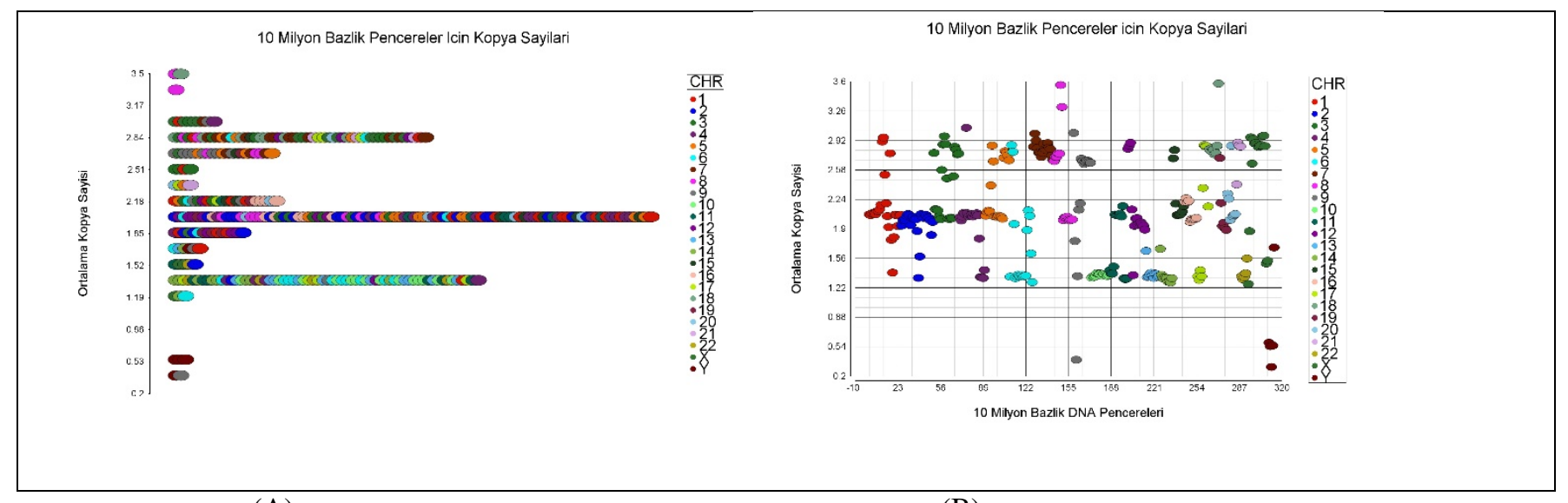

(A)

(B)

Şekil 8. 10 milyon bazlık DNA pencereleri için ortalama kopya sayıları (A) pencerelerin histogram formatında gösterilmiş hali (B) pencerelerin genomdaki sıraya göre $\mathrm{x}$-ekseninde sıralanmış hali 


\subsection{Genel Kopya Sayıları}

$\mathrm{Bu}$ aşamaya kadar mutasyonların sahip olduğu kopya sayıları üzerine yoğunlaştık ve mutlak kopya sayılarını belirledik. Bu bölümde homojen kanser örneğinin genel DNA profilini inceleyeceğiz. Bu amaç doğrultusunda DNA'y1 her biri 10 milyon bazlık 300 civarında pencereye böldük. Homojen bir örnek (T6MC23) için herbir bölgenin ortalama kopya sayısını elde ettik. Ortalama kopya sayıları da daha önceki analizlerimize benzer șekilde mutlak kopya sayısı 2,3 ve 4 olacak şekilde üç bantta toplandı (Şekil 8A). Buna ek olarak 2,3 ve 4 kopyalı bölgelerin genom içinde heterojen (farklı kopya sayıları birçok kromozomda dağılmış şekilde gözlemleniyor) şekilde dağıldığını gözlemledik (Şekil 8B).

\section{DEĞERLENDİRME VE SONUÇ}

Genetik alanındaki teknolojik gelişmeler sayesinde yüksek çözünürlüklü veriler makul fiyatlarla üretilebiliyor. $\mathrm{Bu}$ yeni verilerden faydalı sonuçlar elde edilmesi, ancak verimli analiz metodlarının geliştirilmesi ile mümkün. Analiz metodları dizayn ederken belli önkabuller kullanmamız gerekiyor. Bu önkabullerin seçimi analiz sonuçlarını direk etkileyen önemli bir mesele. $\mathrm{Bu}$ seçimler yapılırken, çoğunlukla genetik bilimi literatüründe sıklıkla kullanılan fakat ispatlanmamış temel anlayışlar kullanılıyor. Dolayısıyla, yeni veriler ışığında bu temel anlayışların doğruluğunun test edilmesi, çalışılması gereken önemli bir problem.

Kanser hücrelerinde silinme ve duplikasyonlar sıkça gözlemlenen olaylardır. Bununla beraber genel profilde kanser hücrelerinin sağlıklı hücrelerdeki iki kopyalı yapıyı devam ettirdiği kabul edilir ve analizler buna göre yapılır. Genel profilde değişim olabileceğini iddia eden çalışmalar ise değişimin homojen olacağını yani kopya sayısının toptan üçe veya dörde çıkacağı kabulü üzerine çalışırlar. Mesela [28] kanser DNA'sının homojen olarak artışı ön kabulü üzerine yapılmış bir çalışmadır. $\mathrm{Bu}$ çalışmamızda yeni nesil sıralama teknolojilerini, tek hücreden elde edilmiş homojen kanser örneklerine uyguladık ve oldukça ilginç sonuçlar elde ettik. İncelediğimiz kanser hücrelerinin ortalama üç kopya sayısına sahip olduğunu ve farklı bölgeler arasında büyük heterojenlik olduğunu gözlemledik. GBM'lerin genetik yapısı ve genetik stabilitesi, bu tümör için geliştireceğimiz tedaviler için göz önünde bulundurmamız gereken önemli unsurlar ve elde ettiğimiz sonuçlar bu unsurlar adına genel kabulleri değiştirebilecek veriler sunuyor. Gözlemlerimiz detaylı çalıştığımız bir GBM tümörüne dayanmakta. Tümör için oluşturduğumuz farklı homojen hücre hatlarında benzer gözlemler yaptık, dolayısı ile sonuçlarımızın doğruluğuna güveniyoruz. Fakat tüm örnekler tek bir hastadan geldiği için genellemeler yapamıyoruz. $\mathrm{Bu}$ genellemeler için farklı tümörlerin analiz edileceği kapsamlı çalışmalar gerekiyor.

\section{TEŞEKKÜR}

$\mathrm{Bu}$ çalışmada kullanılan verilerin üretimine ve yapılan analizlere desteklerinden ötürü Tübitak, Avrupa Komisyonu ve Amerikan Ulusal Kanser Enstitüsü (NCI)'ne teșekkür ederiz.

\section{REFERANSLAR}

[1] M. Baysan et al., "G-Cimp Status Prediction Of Glioblastoma Samples Using mRNA Expression Data," PloS ONE, vol. 7, no. 11, p. e47839, 2012.

[2] B. E. Johnson et al., "Mutational analysis reveals the origin and therapy-driven evolution of recurrent glioma," Science, vol. 343, no. 6167, pp. 189-193, 2014.

[3] T. M. Brown and E. Fee, "Rudolf Carl Virchow: medical scientist, social reformer, role model," American Journal of Public Health, vol. 96, no. 12, p. 2104, 2006. [4] S. Makino, "Further evidence favoring the concept of the stem cell in ascites tumors of rats," Annals of the New York Academy of Sciences, vol. 63, no. 5, pp. 818830, 1956.

[5] G. H. Heppner and B. E. Miller, "Tumor heterogeneity: biological implications and therapeutic consequences," Cancer and Metastasis Reviews, vol. 2, no. 1, pp. 5-23, 1983.

[6] I. J. Fidler and M. L. Kripke, "Metastasis results from preexisting variant cells within a malignant tumor," Science, vol. 197, no. 4306, pp. 893-895, 1977.

[7] I. J. Fidler, "Tumor heterogeneity and the biology of cancer invasion and metastasis," Cancer research, vol. 38, no. 9, pp. 2651-2660, 1978.

[8] N. Navin et al., "Tumour evolution inferred by singlecell sequencing," Nature, vol. 472, no. 7341, pp. 90-94, 2011.

[9] M. Gerlinger et al., "Genomic architecture and evolution of clear cell renal cell carcinomas defined by multiregion sequencing," Nature genetics, vol. 46, no. 3, pp. 225-233, 2014.

[10] J. Zhang et al., "Intratumor heterogeneity in localized lung adenocarcinomas delineated by multiregion sequencing," Science, vol. 346, no. 6206, pp. 256-259, 2014.

[11] L. H. Mengelbier et al., "Intratumoral genome diversity parallels progression and predicts outcome in pediatric cancer," Nat Commun, vol. 6, p. 6125, 2015.

[12] N. McGranahan and C. Swanton, "Biological and Therapeutic Impact of Intratumor Heterogeneity in Cancer Evolution," Cancer cell, vol. 27, no. 1, pp. 15-26, 2015.

[13] D. R. Johnson and B. P. O’Neill, "Glioblastoma survival in the United States before and during the temozolomide era," Journal of neuro-oncology, vol. 107, no. 2, pp. 359-364, 2012. 
[14] D. R. Johnson, H. E. Leeper, and J. H. Uhm, "Glioblastoma survival in the United States improved after Food and Drug Administration approval of bevacizumab: A population-based analysis," Cancer, vol. 119, no. 19, pp. 3489-3495, 2013.

[15] P. Y. Wen and S. Kesari, "Malignant gliomas in adults," New England Journal of Medicine, vol. 359, no. 5, pp. 492-507, 2008.

[16] V. Jung et al., "Evidence of focal genetic microheterogeneity in glioblastoma multiforme by areaspecific CGH on microdissected tumor cells," Journal of Neuropathology \& Experimental Neurology, vol. 58, no. 9, pp. 993-999, 1999.

[17] M. Snuderl et al., "Mosaic amplification of multiple receptor tyrosine kinase genes in glioblastoma," Cancer cell, vol. 20, no. 6, pp. 810-817, 2011.

[18] N. J. Szerlip et al., "Intratumoral heterogeneity of receptor tyrosine kinases EGFR and PDGFRA amplification in glioblastoma defines subpopulations with distinct growth factor response," Proceedings of the National Academy of Sciences, vol. 109, no. 8, pp. 30413046, 2012.

[19] A. Sottoriva et al., "Intratumor heterogeneity in human glioblastoma reflects cancer evolutionary dynamics," Proceedings of the National Academy of Sciences, vol. 110, no. 10, pp. 4009-4014, 2013.

[20] A. P. Patel et al., "Single-cell RNA-seq highlights intratumoral heterogeneity in primary glioblastoma," Science, vol. 344, no. 6190, pp. 13961401, 2014.

[21] A. L. Vital et al., "Intratumoral patterns of clonal evolution in gliomas," Neurogenetics, vol. 11, no. 2, pp. 227-239, 2010.
[22] K. Harada, T. Nishizaki, S. Ozaki, H. Kubota, $\mathrm{H}$. Ito, and K. Sasaki, "Intratumoral cytogenetic heterogeneity detected by comparative genomic hybridization and laser scanning cytometry in human gliomas," Cancer research, vol. 58, no. 20, pp. 46944700, 1998.

[23] S. L. Carter et al., "Absolute quantification of somatic DNA alterations in human cancer," Nature biotechnology, vol. 30, no. 5, pp. 413-421, 2012.

[24] A. Roth et al., "PyClone: statistical inference of clonal population structure in cancer," Nature methods, vol. 11, no. 4, pp. 396-398, 2014.

[25] N. Andor, J. V. Harness, S. Mueller, H. W. Mewes, and C. Petritsch, "EXPANDS: expanding ploidy and allele frequency on nested subpopulations," Bioinformatics, vol. 30, no. 1, pp. 50-60, 2014.

[26] L. Ding et al., "Clonal evolution in relapsed acute myeloid leukaemia revealed by whole-genome sequencing," (in eng), Nature, vol. 481, no. 7382, pp. 506-10, Jan 2012.

[27] M. Baysan et al., "Detailed longitudinal sampling of glioma stem cells in situ reveals Chr7 gain and Chr10 loss as repeated events in primary tumor formation and recurrence," International journal of cancer, vol. 141, no. 10, pp. 2002-2013, 2017.

[28] T. I. Zack et al., "Pan-cancer patterns of somatic copy number alteration," Nature genetics, vol. 45, no. 10, pp. 1134-1140, 2013. 